\title{
FRAUD TRIANGLE SEBAGAI PENDETEKSI KECURANGAN LAPORAN KEUANGAN
}

\author{
Wahyuni dan Gideon Setyo Budiwitjaksono \\ Fakultas Ekonomi dan Bisnis UPN "Veteran" J awa Timur \\ Email :wahyunimiftah@gmail.com dan gidboediono@gmail.com
}

\begin{abstract}
The financial statements are structured representation of the financial position shows the financial performance of an entity. On the other hand, the Financial Services Authority in Indonesia gave the sanction to capital market players for cheating Financial Statements. This shows that the financial statement fraud cases occurring in Indonesia are part of the failure of an audit conducted by the Public Accounting Firm (KAP). This study aims to examine the influence of fraud triangle in detecting fraudulent financial statements. The object of this study using the financial statements of companies listed on the Indonesia Stock Exchange in the 2012-2014 time period. This study uses 123 data samples are taken using purposive criteria. The data were analyzed using multiple linear regression analysis. The results showed that razionalization significant effect on the financial statements fraud. Meanwhile, the financial stability, external pressure, financial targets, the nature of the industry, ineffective monitoring did not significantly affect the financial statements fraud. This study contributes to the regulators to adopt measures to improve the quality of audits, especially in detecting fraud.
\end{abstract}

Keywords: Fraud Triangle, Financial Statement Fraud, Financial Stability, External Pressure, Financial Targets, Nature of Industry, Ineffective Monitoring, Rationalization

Abstrak: Laporan keuangan merupakan penyajian terstruktur dari posisi keuangan yang menunjukkan kinerja keuangan suatu entitas. Di sisi lain, Otoritas Jasa Keuangan di Indonesia meberikan sanksi kepada pelaku pasar modal karena melakukan kecurangan Laporan Keuangan Hal ini menunjukkan bahwa kasus kecurangan laporan keuangan yang terjadi di Indonesia merupakan bagian dari kegagalan audit yang dilakukan oleh Kantor Akuntan Publik (KAP). Penelitian ini bertujuan untuk menguji pengaruh faktor fraud triangle dalam mendeteksi kecurangan suatu laporan keuangan. Objek penelitian ini menggunakan laporan keuangan perusahaan manufaktur yang terdaftar di Bursa Efek Indonesia pada periode waktu 2012-2014. Penelitian ini menggunakan 123 data sampel yang diambil dengan metode purposive berdasarkan kriteria. Analisis data dilakukan dengan menggunakan analisis regresi linear berganda. Hasil penelitian menunjukkan bahwa razionalization berpengaruh signifikan terhadap kecurangan laporan keuangan. Sementara itu, financial stability yang, external pressure, financial targets, nature of industry, ineffective monitoring tidak berpengaruh signifikan terhadap kecurangan laporan keuangan. Penelitian ini memberikan kontribusi bagi regulator dalam menetapkan peraturan untuk meningkatkan kualitas audit terutama dalam mendeteksi kecurangan.

Kata kunci: fraud triangle, kecurangan laporan keuangan, stabilitas keuangan, tekanan pihak luar, target keuangan, karakteristik industri, pengawasan, rasionalisasi 


\section{PENDAHULUAN}

Laporan keuangan merupakan suatu penyajian terstruktur dari posisi keuangan yang menunjukkan kinerja keuangan suatu entitas. Laporan keuangan secara umum bertujuan untuk memberikan informasi mengenai posisi keuangan, kinerja keuangan, dan arus kas entitas yang bermanfaat bagi sebagian besar kalangan pengguna laporan keuangan dalam pembuatan keputusan ekonomi serta menunjukkan pertanggungjawaban manajemen atas penggunaan sumber daya yang dipercayakan kepada mereka (IAI, 2009). Ketika terdapat salah saji material dalam laporan keuangan, maka informasi tersebut menjadi tidak relevan untuk dipakai sebagai dasar pengambilan keputusan karena analisis yang dilakukan tidak berdasarkan informasi yang sebenarnya. Kecurangan sendiri dilakukan dengan berbagai motivasi, salah satunya demi kepentingan pemilik (teori agensi).

Di Indonesia, Otoritas Jasa Keuangan (OJK) berhasil mendeteksi beberapa perusahaan yang terlibat dalam skandal akuntansi. Contoh kasus yang berhasil dideteksi oleh OJK, antara lain PT Sari Husada Tbk, PT Great River Internasional Tbk, PT Agis Tbk dan Katarina Utama Tbk . Beberapa salah saji memang belum tentu berkaitan dengan kecurangan, namun faktor-faktor risiko yang berkaitan dengan kecurangan manajemen terbukti ada pada kasus-kasus ini.

Sepanjang tahun 2014, terdapat 777 pelaku pasar modal yang dikenai sanksi oleh Otoritas Jasa Keuangan (OJK). Atas pelanggaran itu, OJK menerapkan sanksi administratif berupa denda kepada emiten senilai Rp7,9 miliar. Kepala Eksekutif Pengawas Pasar Modal, Otoritas Jasa Keuangan, Nurhaida mengungkapkan, 777 sanksi itu terdiri dari 60 sanksi peringatan tertulis, 713 sanksi denda, 2 sanksi pencabutan izin, dan 2 sanksi pembekuan izin. Nurhaida merinci, sebanyak 665 sanksi administratif berupa denda karena keterlambatan panyampaian laporan berkala dan laporan insidental dengan total niai denda Rp 6,5 miliar. Sedangkan 48 sanksi administratif berupa denda karena kasus pelanggaran ketentuan di bidang pasar modal selain keterlambatan pelaporan dengan nilai total denda Rp1,4 miliar. Sementara 60 sanksi administratif berupa peringatan tertulis, 30 sanksi administratif karena keterlambatan mengumumkan laporan keuangan, serta 30 sanksi administratif berupa peringatan tertulis karena pelanggaran terkait kasus di bidang pasar modal, selain kewajiban pengumuman laporan keuangan. ( Viva News 30 Desember 2014; Sigit A. Nugroho, Romys Binekasri). Berdasarkan realitas atas sanksi yang dikeluarkan OJK sebagaimana diberitakan dalam Viva News, menunjukkan bahwa terdapat kegagalan audit dalam mendeteksi adanya kecurangan laporan keuangan.

Kasus kecurangan laporan keuangan yang terjadi di Indonesia merupakan bagian dari kegagalan audit yang juga dilakukan oleh Kantor Akuntan Publik (KAP) di beberapa negara lainnya. Akuntan Publik di Amerika Serikat dalam hal ini AICPA (American Institute Certified Public Accountant), memberikan solusi untuk mengatasi praktik kecurangan laporan keuangan dalam bentuk Statement of Auditing Standards (SAS). Sementara, International Federation of Accountants (IFAC), sebuah organisasi di Jerman yang menetapkan standar akuntansi, auditing dan kode etik pada tingkat global, juga menerbitkan International Standards on Auditing (ISA). Dalam standar tersebut, terdapat ilustrasi faktor kecurangan, yaitu ISA no. 240 dan SAS no. 99 yang didasarkan pada teori segitiga kecurangan atau fraud triangle. Teori segitiga ini dikemukakan oleh Cressey (1953) yang mengkategorikan tiga kondisi kecurangan di perusahaan, yaitu tekanan (incentive/pressure), peluang (opportunity) dan rasionalisasi (rationalization). 
Teori fraud triangle yang dicetuskan Cressey (1953) sampai saat ini dipakai oleh para praktisi sebagai pendekatan dalam medeteksi suatu tindak kecurangan. Seperti penelitian yang dilakukan oleh Cohen et al. (2008) mengenai peran manajer pada perusahaan yang melakukan kecurangan dengan menggunakan pendekatan teori fraud triangle. Hasil penelitian menunjukan adanya konsistensi dengan pernyataan SAS No. 99 yaitu motif ekonomi selalu muncul pada perusahaan fraud serta faktor psikologi dan adanya kesempatan berperan penting dalam terjadinya kecurangan. Pendekatan teori fraud triangle juga dipakai Albrecht et al. (2010) untuk mengidentifikasi situasi yang menyebabkan perusahaan Chaebol di Korea dalam melakukan kecurangan penelitian. Hasil penelitian menunjukan adanya hubungan keluarga yang kuat di dalam perusahaan memainkan peran yang besar dalam hal tekanan dan kesempatan. Penelitian Lou dan Wang (2009) membuat suatu model melalui pendekatan fraud triangle yang diproksikan ke dalam berbagai kondisi. Hasil penelitian menunjukan bahwa beberapa proksi secara signifikan dapat mendeteksi kecurangan laporan keuangan, di mana proksi-proksi tersebut adalah bagian dari tekanan, kesempatan, dan rasionalisasi. Skousen et al. (2009) juga membuat model pendeteksian kecurangan laporan keuangan yang berbeda dari penelitian Lou dan Wang (2009). Setelah diuji ternyata hanya proksi dari variabel tekanan dan kesempatan saja yang signifikan dalam mendeteksi kecurangan laporan keuangan. Namun model yang dikemukakan Skousen et al. (2009) memiliki tingkat ketepatan prediksi kecurangan laporan keuangan sebesar $73 \%$. Hasil ini menunjukan peningkatan yang substansial dibandingkan dengan model prediksi kecurangan lainnya.

Penelitian yang dilakukan oleh Nguyen (2008), Myers et al. (2006), dan Halim (2005) menyatakan bahwa kecurangan laporan keuangan berkaitan erat dengan tindakan manipulasi laba yang dilakukan oleh manajemen. Manajemen mempunyai peran penting dalam sebuah perusahaan. Manajer mempunyai tanggung jawab untuk mengoptimalkan keuntungan para pemilik, namun disisi lain manajer juga mempunyai kepentingan untuk memaksimumkan kesejahteraan mereka sendiri. Perbedaan inilah yang dapat mempengaruhi kualitas laba yang dilaporkan. Peningkatan yang besar dalam kecurangan laporan keuangan dan kegagalan bisnis telah menimbulkan keprihatinan terhadap legitimasi laporan keuangan suatu perusahaan.

Tindakan kecurangan laporan keuangan masih terus terjadi. Dan pengembangan faktor fraud triangel terus dilakukan oleh berbagai penelitian, terutama pengembangan terhadap proksi yang digunakan. Alasan inilah yang menjadi motivasi dilakukannya penelitian ini, dengan mengajukan pertanyaan penelitian, Apakah faktor fraud triangel (yang terdiri dari financial stability, external pressure, financial targets. nature of industry, ineffective monitoring, organizational structure. dan rationalization) dapat mendeteksi kecurangan laporan keuangan. Adapun tujuan penelitian ini yaitu menguji kemampuan faktor financial stability, external pressure, financial targets. nature of industry, ineffective monitoring, organizational structure. dan rationalization dalam mendeteksi kecurangan laporan keuangan perusahaan manufaktur yang terdaftar di Bursa Efek Indonesia.

\section{KAJIAN TEORI}

Fraud triangle merupakan sebuah teori yang dikemukakan oleh Donald R. Cressey yang mengemukakan hipotesis untuk menjelaskan alasan mengapa orang melakukan fraud. Fraud triangle dapat diibaratkan sebagai fire triangle, dimana pressure dapat 
dianggap sebagai sumber panas yang dapat menyebabkan api. Akan tetapi, Lister (2007) mengungkapkan bahwa pressure sendiri tidak akan dapat membuat seseorang melakukan fraud, kecuali adanya faktor lainnya berupa opportunity atau peluang untuk melakukan fraud yang diibaratkan sebagai bahan bakar yang membuat api tetap menyala dan rasionalisasi dari tindakan pelanggaran yang diibaratkan sebagai oksigennya.

Cressey menemukan bahwa orang melakukan fraud ketika mereka memiliki masalah keuangan yang tidak bisa diselesaikan bersama, tahu dan yakin bahwa masalah tersebut bisa diselesaikan secara diam-diam dengan jabatan/pekerjaan yang mereka miliki dan mengubah pola pikir dari konsep awal sebagai orang yang dipercayai memegang aset menjadi konsep sebagai pengguna dari aset yang dipercayakan kepada mereka. Cressey juga menambahkan bahwa banyak dari pelanggar kepercayaan ini mengetahui bahwa tindakan yang mereka lakukan merupakan tindakan yang ilegal, tetapi mereka berusaha memunculkan pemikiran bahwa apa yang mereka lakukan merupakan tindakan yang wajar. Cressey mengungkapkan bahwa ada 3 faktor yang mendukung seseorang melakukan kecurangan, yaitu masalah keuangan yang harus dirahasiakan (pressure), kesempatan untuk melakukan fraud (opportunity), dan rasionalisasi dari pelaku (razionalization).

Tekanan (pressure) memiliki berbagai arti, yaitu keadaan di mana seseorang merasa ditekan/ tertekan dan kondisi yang berat saat seseorang menghadapi kesulitan. Kedua arti ini menunjukkan bahwa pressure dapat menjadi motivasi bagi seseorang dalam melakukan tindakan. Menurut SAS No.99, terdapat empat jenis kondisi yang umum terjadi pada pressure yang dapat mengakibatkan kecurangan. Kondisi tersebut adalah financial stability, external pressure, personal financial need, dan financial targets. Financial stability merupakan keadaan yang menggambarkan kondisi keuangan perusahaan pada kondisi stabil. Kondisi keuangan perusahaan dikatakan stabil apabila perusahaan dapat mencukupi kebutuhan rutin saat ini, kebutuhan yang akan datang, hingga kebutuhan yang sifatnya mendadak/tiba-tiba sekalipun. Ketika suatu perusahaan berada dalam kondisi stabil maka nilai perusahaan akan naik dalam pandangan investor, kreditur dan publik. Oleh karena itu manajer akan melakukan berbagai cara agar financial stability perusahaan terlihat stabil. Menurut SAS No. 99, manajer menghadapi tekanan untuk melakukan kecurangan ketika stabilitas keuangan atau profitabilitas terancam oleh keadaan ekonomi, industri, dan situasi entitas yang beroperasi (Skousen et al., 2009).

Berdasarkan hasil penelitian Mulford (2010) menyimpulkan bahwa prosentase perubahan total aset mengidikasikan adanya kecurangan pada laporan keuangan, karena tingginya prosentase perubahan total aset sebagai cara untuk menunjukkan earning power perusahaan dan posisi finansial yang lebih kuat. Berdasarkan teori dan dari hasil penelitian sebelumnya, maka financial stability perusahaan dapat menjadi salah satu faktor yang dapat digunaan untuk mendeteksi terjadinya kecurangan laporan keuangan.

H1: Financial stability dapat digunakan untuk mendeteksi kecurangan laporan keuangan.

External Pressure merupakan tekanan yang berlebihan bagi manajemen untuk memenuhi persyaratan atau harapan dari pihak ketiga. Skousen et al., (2009) menjelaskan bahwa manajer mungkin merasa bahwa tekanan sebagai salah satu cara untuk memperoleh tambahan utang atau pembiayaan ekuitas agar tetap kompetitif. Di sisi lain perusahaan diwajibkan mengembalikan hutang yang telah diperolehnya. Suatu perusahaan dikatakan mampu mengembalikan hutang apabila kegiatan operasionalnya berlangsung terus menerus dan tidak mengalami rugi. Apabila perusahaan memiliki rasio leverage yang 
tinggi maka perusahaan tersebut memiliki hutang yang besar dan menghadapi risiko kredit yang juga tinggi. Timbulnya hutang dalam suatu perusahaan seringkali menyebabkan manajemen untuk melaporkan profitabilitas yang tinggi. Sehingga tidak jarang perusahaan melakukan kecurangan pelaporan keuangan dengan cara menaikkan laba yang diperolehnya.

Hasil penelitian Vermeer, Press dan Weintrop sebagaimana dikutip dari Skousen et al. (2009) menyimpulkan bahwa saat dilakukan pelunasan pinjaman, manajer kemungkinan melakukan diskresionari akrual. Berdasarkan teori dan dari hasil penelitian sebelumnya, maka External Pressure yang dialami oleh manajemen perusahaan dapat menjadi salah satu faktor yang dapat digunaan untuk mendeteksi terjadinya kecurangan laporan keuangan.

$\mathbf{H}_{2}$ : External pressure dapat digunakan untuk mendeteksi kecurangan laporan keuangan.

Financial targets merupakan tekanan berlebihan pada manajemen untuk mencapai target keuangan yang direncanakan oleh direksi atau manajemen. Dalam menjalankan kinerjanya, manajer perusahaan dituntut melakukan pengelolaan terbaik dalam pencapaian target yang telah direncakan. ROA (Return On Asset) merupakan rasio profitabilitas yang digunakan untuk mengukur efektifitas perusahaan dalam menghasilkan keuntungan dengan memanfaatkan aktiva yang dimilikinya (Skousen et al., 2009). ROA sering digunakan dalam menilai kinerja manajer dan dalam menentukan bonus, kenaikan upah, dan lain-lain.

Hasil penelitian Summerrs dan Sweeney (1998) sebagaimana dikutip dari (Skousen et al., 2009) dan penelitian Carlson dan Bathala (1997) sebagaimana dikutip dari Widyastuti (2009) menyimpulkan bahwa ROA secara signifikan berbeda antara fraud firm dan non fraud firm. Dan perusahaan yang memiliki laba besar, yang diukur dengan profitabilitas atau ROA, lebih memungkinkan dilakukannya manajemen laba daripada perusahaan yang memiliki laba yang kecil. Berdasarkan teori dan dari hasil penelitian sebelumnya, maka Financial targets yang digunakan oleh manajemen untuk mengukur kinerja perusahaan dapat menjadi salah satu faktor yang dapat digunaan untuk mendeteksi terjadinya kecurangan laporan keuangan.

$\mathbf{H}_{3}$ : Financial Targets dapat digunakan untuk mendeteksi kecurangan laporan keuangan.

Opportunity (Peluang) merupakan situasi atau kondisi yang memungkinkan terjadinya kecurangan. Peluang terjadi karena adanya kelemahan pengendalian internal, ketidakefektifan pengawasan manajemen, atau penyalahgunaan posisi atau otoritas. SAS No.99 menyebutkan bahwa peluang pada kecurangan laporan keuangan dapat terjadi pada tiga kategori kondisi. Kondisi tersebut adalah nature of industry, ineffective monitoring, dan organizational structure. Nature of industry berkaitan dengan munculnya risiko bagi perusahaan yang berkecimpung dalam industri yang melibatkan estimasi dan pertimbangan yang signifikan jauh lebih besar. Peluang merupakan akibat dari keadaan yang memberikan kesempatan untuk melakukan kecurangan. Transaksi pihak istimewa yang rumit yang disertai dengan risiko inheren yang tinggi karena keterlibatan pihak manajemen dalam pengambilan keputusan dan subjektif. Selain itu, traksaksi dengan pihak istimewa yang kompleks dapat menimbulkan risiko salah saji material karena rentan terhadap manipulasi oleh manajemen.

Hasil penelitian Lou dan Wang (2009) menyimpulkan bahwa bila prosentase yang lebih tinggi pada transaksi kompleks muncul, perusahaan memiliki probabilitas yang lebih 
besar melakukan kecurangan. Sementara penelitian Young (2005) menyimpulkan bahwa transaksi dengan pihak yang diduga mempunyai hubungan istimewa dapat memotivasi manipulasi laba, penjarahan perusahaan, dan melakukan kecurangan. Berdasarkan teori dan dari hasil penelitian sebelumnya, maka nature of industry yang dimiliki perusahaan dapat menjadi salah satu faktor yang dapat digunaan untuk mendeteksi terjadinya kecurangan laporan keuangan.

$\mathbf{H}_{4}$ : Nature of industry dapat digunakan untuk mendeteksi kecurangan laporan keuangan.

Ineffective monitoring merupakan keadaan suatu perusahaan tidak memiliki unit pengawas yang efektif untuk memantau kinerja perusahaan. Terjadinya praktik kecurangan atau fraud merupakan salah satu dampak dari pengawasan atau monitoring yang lemah, sehingga memberi kesempatan kepada agen atau manajer untuk berperilaku menyimpang dengan melakukan manajemen laba (Andayani, 2010). Praktik kecurangan atau fraud dapat diminimalkan salah satunya dengan mekanisme pengawasan yang baik. Dewan komisaris independen dipercaya dapat meningkatkan efektivitas pengawasan perusahaan. Dewan komisaris bertugas untuk menjamin terlaksananya strategi perusahaan, mengawasi manajemen dalam mengelola perusahaan serta mewajibkan terlaksananya akuntabilitas (Forum for Corporate Governance in Indonesia, 2003).

Hasil penelitian Gunarsih dan Hartadi (2002) menyimpulkan bahwa dewan komisaris secara luas dapat dipercaya memberikan peran penting khususnya dalam memonitor manajemen tingkat atas. Dan penelitian Andayani (2010) menyimpulkan bahwa komisaris independen yang merupakan bagian dari dewan komisaris sangat berperan dalam meminimumkan manajemen laba yang merupakan salah satu bentuk financial statement fraud yang dilakukan oleh pihak manajemen. Berdasarkan teori dan dari hasil penelitian sebelumnya, maka Ineffective monitoring yang dilakukan dewan komisaris dalam melakukan pengawasan operasional perusahaan yang dilakukan manajemen menjadi salah satu faktor yang dapat digunaan untuk mendeteksi terjadinya kecurangan laporan keuangan.

$\mathbf{H}_{5}$ : Ineffective monitoring dapat digunakan untuk mendeteksi kecurangan laporan keuangan.

Organizational structure merupakan struktur organisasi yang kompleks dan tidak stabil. Struktur organisasi yang kompleks atau tidak stabil dapat ditunjukkan dengan tingginya perputaran posisi manajer senior, konsultan, dan jajaran direksi sebuah perusahaan (Skousen et al., 2009). Adanya pergantian struktur jajaran direksi biasanya diikuti dengan praktik manajemen laba. Hal ini karena pada saat mendekati masa akhir jabatannya, manajemen akan memaksimalkan bonusnya. Pergantian jajaran direksi pada suatu perusahaan dapat menjadi faktor terjadinya kecurangan laporan keuangan. Berdasarkan teori, maka Organizational structure yang ditunjukkan oleh pergantian jajaran direksi dalam perusahaan menjadi salah satu faktor yang dapat digunaan untuk mendeteksi terjadinya kecurangan laporan keuangan.

H6 : Organizational structure dapat digunakan untuk mendeteksi kecurangan laporan keuangan.

Rationalization (Rasionalisasi) yang dijelaskan dalam Pernyataan Standar Auditor (PSA) No. 70 menunjukkan bahwa terdapat ketegangan hubungan antara manajemen dengan auditor sekarang/auditor pendahulu sebagai indikasi tindak kecurangan pelaporan 
keuangan. Sorenson et al., (1983) berpendapat bahwa klien bisa mengganti auditor untuk mengurangi kemungkinan deteksi kecurangan pelaporan keuangan.

Hasil penelitian Summers and Sweeny (1998) sebagaimana dikutip dari Gagola (2011) menyimpulkan bahwa klien dapat menggunakan mekanisme perpindahan auditor (auditor switch) untuk mengurangi kemungkinan pendeteksian tindak kecurangan laporan keuangan yang dilakukan oleh perusahaan. Penelitian Loebbecke et al., (1989) sebagaimana dikutip dari Lou and Wang (2009) menyimpulkan bahwa dari 36 persen sampel yang melakukan tindak kecurangan, mereka dituduhkan dalam dua tahun awal masa jabatan auditor. Sementara penelitian Stice (1991) menyimpulkan bahwa risiko kegagalan audit dan litigasi berikutnya dalam keterlibatan awal lebih tinggi dibandingkan dengan tahun-tahun berikutnya. Dan penelitian Krishnan (2005) dan Shu (2000) menyimpulkan bahwa pengunduran diri auditor berpengaruh positif terhadap kemungkinan litigasi. Berdasarkan teori dan dari hasil penelitian sebelumnya, maka Rationalization dengan melakukan penggantian auditor dalam perusahaan menjadi salah satu faktor yang dapat digunaan untuk mendeteksi terjadinya kecurangan laporan keuangan.

H7 : Rationalization dapat digunakan untuk mendeteksi kecurangan laporan keuangan.

\section{METODE}

Penelitian ini menggunakan populasi sebanyak 426 perusahaan manufaktur yang terdaftar dalam Bursa Efek Indonesia selama periode 2012-2014. Dengan menggunakan teknik purposive sampling berdasarkan kriteria, diperoleh sampel penelitian sejumlah 123 data laporan keuangan perusahaan manufaktur. Data dikumpulkan dengan menggunakan metode dokumentasi dengan mengunduh secara langsung laporan keuangan perusahaan manufaktur yang dipublikasikan di website www.idx.co.id. Untuk menguji hipotesis penelitian, data dianalisis dengan menggunakan teknik analisis regresi linier berganda melalui software SPSS.

Variabel Dependen. Penelitian ini menggunakan variabel dependen yaitu kecurangan laporan keuangan yang diproksikan dengan manajemen laba. Manajemen laba (DACC) diukur melalui discretionary accrual yang dihitung dengan cara menyelisihkan total accruals (TACC) dan nondiscretionary accruals (NDACC). Discretionary accruals (DACC) merupakan tingkat akrual yang tidak normal yang berasal dari kebijakan manajemen untuk melakukan rekayasa terhadap laba sesuai dengan yang mereka inginkan. Dalam menghitung DACC, digunakan Modified Jones Model. Model Modified Jones dianggap dapat mendeteksi manajemen laba yang lebih baik dibandingkan dengan modelmodel yang lain, sejalan dengan penelitian Dechow et al. (1995) dalam Ujiyantho dan Pramuka (2007). Model perhitungannya modifikasi Jones, yaitu:

$\mathrm{TA}_{\text {it }}=\mathrm{NI}_{\text {it }}-\mathrm{CFO}_{\text {it }}$

$\mathrm{TA}_{\mathrm{it}}=\mathrm{NDA}_{\mathrm{it}}+\mathrm{DA}_{\mathrm{it}}$

$\mathrm{TA}_{\mathrm{it}} / \mathrm{A}_{\mathrm{it}-1}=\beta 1\left(1 / \mathrm{A}_{\mathrm{it}-1}\right)+\beta 2\left(\Delta \mathrm{Rev}_{\mathrm{t}} / \mathrm{A}_{\mathrm{it}-1}\right)+\beta 3\left(\mathrm{PPE}_{\mathrm{t}} / \mathrm{A}_{\mathrm{it}-1}\right)+\mathrm{e}$

Dengan menggunakan koefisien regresi pada persamaan (3) di atas, maka nilai non discretionary accruals (NDA) dapat diperoleh dengan rumus: 
$\mathrm{NDA}_{i t}=\beta 1\left(1 / \mathrm{Ai}_{\mathrm{t}}-1\right)+\beta 2\left(\Delta \mathrm{Rev}_{\mathrm{it}} / \mathrm{Ai}_{\mathrm{t}}-1-\Delta \mathrm{Rec}_{\mathrm{t}} / \mathrm{Ai}_{\mathrm{t}-1}\right)+\beta 3\left(\mathrm{PPE}_{\mathrm{t}} / \mathrm{Ai}_{\mathrm{t}-1}\right) \ldots$

Selanjutnya nilai discretionary accruals (DA) dapat dihitung sebagai berikut:

$\mathrm{DA}_{\mathrm{it}}=\mathrm{TA}_{\mathrm{it}} / \mathrm{Ai}_{\mathrm{t}-1}-\mathrm{NDA}_{\mathrm{it}}$

$\mathrm{DA}_{\mathrm{it}}=\left(\mathrm{TA}_{\mathrm{t}} / \mathrm{Ai}_{\mathrm{t}-1}\right)-\left[\left(\beta 1\left(1 / \mathrm{Ai}_{\mathrm{t}-1}\right)+\beta 2\left(\Delta \mathrm{ReV}_{\mathrm{it}} / \mathrm{Ai}_{\mathrm{t}-1}-\Delta \mathrm{Rec}_{\mathrm{t}} / \mathrm{Ait}_{-1}\right)+\beta 3\left(\mathrm{PPE}_{\mathrm{t}} / \mathrm{Ai}_{\mathrm{t}-1}\right)\right]\right.$

Keterangan:

$\mathrm{TA}_{\mathrm{it}}=$ Total akrual perusahaan $\mathrm{i}$ pada tahun $\mathrm{t} ; \mathrm{NI}_{\mathrm{it}}=$ Laba bersih (net income) perusahaan $\mathrm{i}$ pada tahun $\mathrm{t} ; \mathrm{CFO}_{\mathrm{it}}=$ Kas dari operasi (cash flow from operation) perusahaan i pada tahun $\mathrm{t}$; $\mathrm{NDA}_{\mathrm{it}}=$ Non discretionary accrual perusahaan i pada tahun $\mathrm{t}$; $\mathrm{DA}_{\mathrm{it}}=$ Discretionary accrual perusahaan i pada tahun $\mathrm{t} ; \Delta \operatorname{Rev}_{\mathrm{it}}=$ Pendapatan perusahaan $\mathrm{i}$ pada tahun $\mathrm{t}$ dikurangi pendapatan tahun $\mathrm{t}-1 ; \Delta \mathrm{Rec}_{\mathrm{t}}=$ Perubahan piutang perusahaan $\mathrm{i}$ pada tahun $\mathrm{t}$; $\mathrm{PPE}_{\mathrm{it}}=$ Aktiva tetap perusahaan $\mathrm{i}$ pada tahun $\mathrm{t} ; \mathrm{Ai}_{\mathrm{t}-1}=$ Total aktiva perusahaan i pada tahun $\mathrm{t}-1 ; \mathrm{e}_{\mathrm{it}}=$ Error term perusahaan i pada tahun $\mathrm{t}$.

Variabel Independen. Penelitian ini menggunakan variabel independen antara lain financial stability yang diproksikan dengan rasio total perubahan aset (ACHANGE), external pressure yang diproksikan dengan rasio leverage (LEV), financial target yang diproksikan dengan return on asset (ROA), nature of industry yang diproksikan dengan rasio transaksi pihak istimewa (RPT), ineffective monitoring yang diproksikan dengan rasio komisaris independen (BDOUT), organizational structure yang diproksikan dengan pergantian posisi pejabat eksekutif tertinggi (TURN), razionalization yang diproksikan dengan pergantian Kantor Akuntan Publik (AUDCHANG).

Financial Stability menggunakan proksi rasio perubahan aset selama dua tahun. Rasio perubahan aset yang disimbolkan dengan ACHANGE dihitung dengan rumus yang dikemukakan Skousen et al. (2008):

$$
A C H A N G E=\frac{\text { total aset }(t)-\text { total aset }(t-1)}{\text { total aset }}
$$

External Pressure menggunakan proksi leverage yang dihitung dengan rumus:

$$
L E V=\frac{\text { Total hutang }}{\text { Total aset }}
$$

Financial Targets diukur dengan menggunakan proksi ROA yang dihitung dengan rumus:

$$
R Q A=\frac{\text { Lababersih }}{\text { Total aset }}
$$

Nature of Industry diproksikan dengan transaksi pihak istimewa (RPT) yang diukur dengan:

$$
R P T=\frac{\text { Total piutang usahahubungan istimewa }}{\text { Total piutangusaha keseluruhan perusahaan }}
$$


Ineffective Monitoring menggunakan proksi proporsi jumlah dewan komisaris independen (BDOUT) yang dihitung dengan rumus:

$$
\text { BDOUT }=\frac{\text { Jumlah komisarisindependen }}{\text { Jumlah dewan komisaris }}
$$

Organizational Structure menggunakan proksi jumlah direksi yang meninggalkan perusahaan selama dua tahun (TURN) yang memiliki hubungan positif dengan kecurangan laporan keuangan. Perpindahan direksi menggunakan variabel dummy, jika perusahaan melakukan pergantian direksi selama (t-1) atau (t-2) sebelum kecurangan maka diberi kode 1 (satu), jika perusahaan tidak melakukan perpindahan direksi maka diberi kode 0 (nol).

Rationalization menggunakan proksi pergantian KAP yang disimbolkan dengan AUDCHANG. Pergantian KAP menggunakan variabel dummy, kode 1 (satu) jika perusahaan melakukan pergantian KAP selama periode (t-1) atau (t-2), kode 0 (nol) jika tidak melakukan pergantian KAP.

Teknik Analisis dan Uji Hipotesis. Pengujian pengaruh variabel independen dalam hal ini financial stability, external pressure, personal financial need, financial target, nature of industry, ineffective monitoring, organizational structure, dan razionalitation terhadap variabel dependen, kecurangan laporan keuangan, dilakukan dengan menggunakan model persamaan regresi sebagai berikut:

DACCit $=\beta_{0}+\beta_{1}$ ACHANGE $+\beta_{2} \mathrm{LEV}+\beta_{3} \mathrm{ROA}+\beta_{4} \mathrm{RPT}+\beta_{5} \mathrm{BDOUT}+\mathrm{D}_{1} \mathrm{TURN}+$ $\mathrm{D}_{2} \mathrm{AUDCHANG}+$

Keterangan: DACCit $=$ discretionary accruals perusahaan $\mathrm{i}$ tahun $\mathrm{t}$; $\mathrm{ACHANGE}=$ Perubahan aset;LEV = Leverage; OSHIP = Kepemilikan saham oleh orang dalam; ROA RPT $=$ Transaksi pihak istimewa; BDOUT = Dewan komisaris independen;TURN= Pergantian direksi; AUDCHANG $=$ Pergantian Kantor Akuntan Publik (KAP); $\beta_{0}=$ Konstanta; $\beta_{1}-\beta_{5}=$ Koefisien regresi; $\mathrm{D}_{1}-\mathrm{D}_{2}=$ Variabel Dummy; = error

\section{HASIL DAN PEMBAHASAN}

Analisis Data. Penelitian terhadap 123 data laporan keuangan perusahaan manufaktur di Bursa Efek Indonesia pada periode tahun 2012-2014, sebelumnya telah memenuhi uji asumsi klasik seperti Uji normalitas, heteroskedastisitas, multikolinieritas dan uji autokorelasi. Berdasarkan analisis regresi berganda menunjukkan hasil seperti Tabel 1.

Financial stability. Berdasarkan Tabel 1 dapat diketahui nilai t hitung sebesar 1.576, dengan tingkat signifikansi sebesar $0,118(>0,05)$, maka hipotesis yang menyatakan Financial stability dapat digunakan untuk mendeteksi kecurangan laporan keuangan, dinyatakan ditolak. Hal ini berarti semakin besar perubahan aset perusahaan sebagai proksi financial stability menyebabkan semakin kecil praktik manajemen laba sebagai proksi kecurangan laporan keuangan. 
Tabel 1. Hasil Analisis Data Regresi Linear

\begin{tabular}{|c|c|c|c|c|c|}
\hline \multirow{2}{*}{ Model } & \multicolumn{2}{|c|}{$\begin{array}{l}\text { Unstandardized } \\
\text { Coefficients }\end{array}$} & \multirow{2}{*}{$\begin{array}{l}\text { Standardized } \\
\text { Coefficients }\end{array}$} & \multirow{2}{*}{$\mathrm{t}$} & \multirow{2}{*}{ Sig. } \\
\hline & B & Std. Error & & & \\
\hline (constant) & .044 & .100 & & .439 & .661 \\
\hline ACHANGE & .301 & .191 & .133 & 1.576 & .118 \\
\hline LEV & -.171 & .130 & -.121 & -1.309 & .193 \\
\hline ROA & -.561 & .323 & -.174 & -1.739 & .085 \\
\hline RPT & .012 & .068 & .016 & .180 & .857 \\
\hline BDOUT & .189 & .172 & .094 & 1.098 & .274 \\
\hline TURN & -.005 & .045 & -.009 & -.103 & .918 \\
\hline AUDCHANGE & .367 & .070 & .501 & 5.278 & .000 \\
\hline
\end{tabular}

a. Dependent Variable: DACCit

Perubahan aset yang besar menyebabkan perusahaan mendapat sorotan dari masyarakat dan informasi mengenai perusahaan tersebut cepat menyebar. Perusahaan yang memiliki perubahan aset besar akan mendapat kepercayaan dari masyarakat, pemerintah, investor, dan kreditur dengan harapan memperoleh tingkat pengembalian yang besar (Solechan, 2009). Nasution (2007), juga menyatakan perusahaan besar lebih berhati-hati dalam melakukan pelaporan keuangan, sehingga berdampak pada perusahaan yang melaporkan kondisinya lebih akurat. Oleh karena itu, perusahaan akan menjaga kredibilitas perusahaan di mata publik dengan mengurangi praktik manajemen laba, sehingga perusahaanperusahaan akan menghindari tersebarnya informasi tentang praktik-praktik kecurangan yang dilakukan perusahaan. Perusahaan akan tetap menjaga citranya agar informasi yang menyebar adalah informasi yang baik dan dapat menarik investor untuk berinvestasi. Hasil penelitian ini mendukung/ konsisten penelitian Lou dan Wang (2009), Chtourou (2001), Norbarani (2012) dan Yayuk (2014), tetapi bertentangan dengan penelitian Skousen et al. (2008) dan Rusli (2009) yang menyatakan bahwa perubahan aset pada perusahaan mempunyai pengaruh terhadap manajemen laba.

External Pressure. Berdasarkan tabel 1 dapat diketahui nilai t hitung sebesar -1.309 , dengan tingkat signifikansi sebesar 0,193 (>0,05), maka hipotesis yang menyatakan External pressure dapat digunakan untuk mendeteksi kecurangan laporan keuangan, dinyatakan ditolak. Hal ini berarti mayoritas perusahaan tidak membiayai aktiva dengan menggunakan utang, sehingga tidak ada pengaruh yang kuat terhadap keputusan manajemen perusahaan terhadap jumlah laba yang akan dilaporkan apabila terjadi perubahan pada tingkat hutang perusahaan, hal ini disebabkan karena perusahaan mampu melunasi pokok beserta bunga pinjamannya. Demikian sebaliknya, ketika Leverage mengalami penurunan, maka manajemen laba akan meningkat. Hal ini karena perusahaan melakukan tindakan manajemen laba tidak selamanya untuk memberikan kepercayaan kepada pihak kreditur tetapi lebih karena perusahaan mampu membiayai kegiatan operasionalnya lebih banyak dengan menggunakan modal sendiri. Hasil penelitian ini mendukung/ konsisten dengan penelitian Skousen et al. (2008) dan Sukirman (2013) yang menyatakan external pressure dengan proksi leverage tidak berpengaruh signifikan terhadap kecurangan laporan keuangan dengan proksi manajemen laba. Namun hasil penelitian ini tidak sejalan/ bertentangan dengan penelitian Manurung (2013), Lou dan 
Wang (2009), serta Herawaty (2010) yang menyatakan bahwa leverage atau besarnya hutang merupakan salah satu faktor yang memotivasi terjadinya manajemen laba, yang berpengaruh positif terhadap kecurangan laporan keuangan.

Financial Targets. Berdasarkan tabel 1 dapat diketahui nilai t hitung sebesar -1.739 , dengan tingkat signifikansi sebesar 0,085 (>0,05), maka hipotesis yang menyatakan Financial Targets dapat digunakan untuk mendeteksi kecurangan laporan keuangan, dinyatakan ditolak. Hal ini berarti pada kondisi ROA perusahaan naik, menunjukkan perusahaan tersebut mampu menghasilkan laba dari aset perusahaan, sedangkan untuk mendanai investasi aset sumber dananya berasal dari penjualan saham. Harga saham pada dasarnya sangat terkait dengan kondisi keuangan perusahaan, jika penghasilan perusahaan tinggi, maka keyakinan investor juga tinggi sehingga harga saham juga tinggi. Harga saham yang tinggi menyebabkan pembayaran deviden juga besar. Oleh karena itu, manajemen tidak bisa melakukan manajemen laba. Sedangkan pada kondisi ROA rendah, maka investor mengabaikan ROA yang ada secara maksimal, sehingga membuat manajemen menjadi tidak termotivasi untuk melakukan manajemen laba. Hasil penelitian ini konsisten dengan penelitian Noviana dan Etna (2010), Santoso (2009), dan Andri (2014) yang menyatakan bahwa return on asset tidak berpengaruh signifikan terhadap manajemen laba. Namun, penelitian ini tidak sejalan/ bertentangan dengan penelitian Skousen et al. (2008) dan Lou dan Wang (2009), yang menyatakan bahwa financial targets berpengaruh terhadap kecurangan laporan keuangan.

Nature of Industry. Berdasarkan tabel 1 dapat diketahui nilai t hitung sebesar 0.180, dengan tingkat signifikansi sebesar 0,857 (>0,05), maka hipotesis yang menyatakan Nature of industry dapat digunakan untuk mendeteksi kecurangan laporan keuangan, dinyatakan ditolak. Hal ini berarti perusahaan melakukan manajemen laba terkait dengan adanya transaksi dengan pihak istimewa pada saat perusahaan melakukan penerbitan saham perdana atau Initial Public Offering (IPO). Perusahaan melakukan manajemen laba dengan menaikkan penjualan dengan pihak-pihak istimewa termasuk penjualan secara kredit sehingga laba penjualan meningkat pada periode IPO yang menyebabkan investor akan tertarik untuk membeli saham perusahaan karena investor melihat laba perusahaan yang tinggi (Aharony et al., 2010 ; Jian et al., 2003; Herman, 2013; dan Dewi, 2013). Hasil penelitian ini konsisten dengan penelitian Feliana (2007) dan Andri (2014) yang menyatakan bahwa transaksi pihak istimewa tidak berpengaruh signifikan terhadap manajemen laba. Namun, penelitian ini tidak mendukung dengan penelitian Lou dan Wang (2009).

Ineffective Monitoring. Berdasarkan tabel 1 dapat diketahui nilai t hitung sebesar 1.098, dengan tingkat signifikansi sebesar 0,274 $(>0,05)$, maka hipotesis yang menyatakan Ineffective monitoring dapat digunakan untuk mendeteksi kecurangan laporan keuangan, dinyatakan ditolak. Hal ini berarti porsi dewan komisaris independen menunjukkan komposisi dewan komisaris, namun tidak menunjukkan kualitas peran dewan yang dapat mempengaruhi praktik manajemen laba (Sarkar et al.,2006 dalam Restuningdiah, 2011). Hal tersebut menunjukkan bahwa dewan komisaris yang memiliki banyak pekerjaan dan tidak mempunyai waktu untuk perusahaan karena kesibukannya akan menimbulkan praktik manajemen laba (Chtourou, 2001 dan Restuningdiah, 2011). Hasil penelitian ini konsisen dengan penelitian Skousen et al. (2008), Restuningdiah (2010), Sukirman (2012) 
dan Andri (2014) yang menyatakan bahwa porsi dewan komisaris independen tidak berpengaruh signifikan terhadap manajemen laba. Namun, penelitian ini tidak sejalan dengan penelitian Kusumawardhani (2012) serta Rahmawati dan Utami (2008).

Organizational Structure. Berdasarkan tabel 1 dapat diketahui nilai t hitung sebesar 0.103 , dengan tingkat signifikansi sebesar $0,918(>0,05)$, maka hipotesis yang menyatakan Organizational structure dapat digunakan untuk mendeteksi kecurangan laporan keuangan, dinyatakan ditolak. Hal ini berarti semakin tinggi tingkat transparansi sebuah perusahaan, menunjukkan intervensi direksi perusahaan terhadap manajemen laba semakin kecil, baik saat dijabat oleh direksi baru ataupun direksi lama. Sehingga keberadaan direksi baru atau lama atau terjadinya pergantian direksi tidak mampu mempengaruhi praktik manajemen laba. Hal ini tergantung dari budaya atau gaya manajemen perusahaan tersebut. Sama seperti adanya dewan komisaris, keberadaan direksi baik lama atau baru juga tidak berpengaruh pada manajemen laba karena semua tergantung pada masing-masing pribadi dari direksi tersebut. Hasil penelitian ini sejalan dengan penelitian Lou dan Wang (2009). Namun tidak sejalan dengan penelitian Kurniawati dan Raharja (2012) dan Skousen et al. (2008).

Rationalization. Berdasarkan tabel 1 dapat diketahui nilai t hitung sebesar 5.278, dengan tingkat signifikansi sebesar $0,000 \quad(<0,05)$, maka hipotesis yang menyatakan Rationalization dapat digunakan untuk mendeteksi kecurangan laporan keuangan, dinyatakan diterima. Hal ini berarti ketika klien mencari auditor baru, berarti terjadi ketidaksimetrisan informasi antara auditor dengan klien. Hal ini karena informasi yang dimiliki klien lebih besar dibandingkan informasi yang dimiliki auditor yang baru (Wijayanti, 2008) dalam Abdillah (2013). Pergantian auditor dapat memberikan perubahan kondisi yang dapat menekan praktik manajemen laba. Hasil penelitian ini sejalan dengan penelitian Lou dan Wang (2009) dan Sukirman (2012), yang menyatakan bahwa salah satu komponen dari fraud triangle, yaitu rasionalisasi berpengaruh signifikan terhadap manajemen laba. Namun, penelitian ini tidak sejalan dengan penelitian Skousen et al. (2008) yang tidak mampu menemukan pengaruh proksi rasionalisasi terhadap kecurangan laporan keuangan.

\section{PENUTUP}

Simpulan. (1) Financial stability, External Pressure, Financial Targets, Nature of Industry, Ineffective Monitoring dan Organizational Structure tidak berpengaruh terhadap kecurangan laporan keuangan. Artinya rasio perubahan asset, leverage, return on assets, transaksi pihak istimewa, proporsi jumlah dewan komisaris independen dan direksi yang meninggalkan perusahaan, masing-masing tidak dapat digunakan untuk mendeteksi kecurangan laporan keuangan. (2) Razionalization berpengaruh positif terhadap kecurangan laporan keuangan. Artinya pergantian KAP mampu digunakan sebagai pendeteksi kecurangan laporan keuangan.

Saran. (1) Adanya penambahan variabel-variabel lain yang menggunakan proksi seperti latar belakang komisaris independen dari akademisi dan praktisi. (2) Peneliti selanjutkan disarankan memperluas sampel perusahaan selain sektor manufaktur dan menambah periode pengamatan (3) Regulator disarankan dapat menetapkan kebijakan yang kondusif 
yang dapat menjadi mekanisme pengendalian bagi seluruh pemangku kepentingan khususnya berkaitan dengan penyajian informasi keuangan suatu perusahaan.

\section{DAFTAR RUJUKAN}

Abdillah, Titis Bonang. (2013) "Faktor-Faktor yang Mempengaruhi Pergantian KAP". Diponegoro Journal of Accounting, Vol. 2 (3), 1-12. Diakses : <http://ejournals1.undip.ac.id>

Aharony, J., Wang, J., dan Yuan, H. (2010) “Tunneling As An Incentive For Earnings Management During the IPO Process in China". Journal of Accounting and Public Policy, Vol. 55 (1), 81-105.

AICPA, SAS No. 99. (2002) "Consideration of Fraud in a Financial Statement Audit, AICPA". New York.

Albrecht, C., Turnbull, C., Zhang, Y. and Skousen, C. J. (2010) "The relationship between South Korean chaebols and fraud". Managerial Auditing Journal, 33(3), 1-25. Retrieved from www.emerald.com

Andayani, Tutut Dwi. (2010) "Pengaruh karakteristik dewan komisaris independen terhadap manajemen laba". Tesis. Program Pascasarjana Universitas Diponegoro Program Studi Magister Sains

Andi, (2014) Analisis Data Penelitian dengan SPSS 22, Penerbit Wahana Komputer, Yogyakarta

Andri, Yayuk Susanti. (2014) "Pendeteksian Kecurangan Laporan Keuangan Dengan Analisis Fraud Triangle", Skripsi Tidak Dipublikasikan, Fakultas Ekonomi dan Bisnis, Universitas Airlangga.

Chtourou, Sonda M. (2001) "Corporate Governance and Earnings Management". Paper of Departement des Sciences Comptables Universite Laval. Diakses: http://search.proquest.com

Cohen, J., Ding Y., Lesage, C., Stolowy, H. (2008) "The Role of Managers Behaviour in Corporate Fraud. Working Paper". Boston College-HEC Paris (SSRN)

Cressey, D.R (1953) Other people's money, dalam: "Detecting and Predicting Financial Statement Fraud: The Effectiveness of The Fraud Triangle and SAS No. 99", Skousen et al. 2009. Journal of Corporate Governance and Firm Performance, 13: 53-81

Dewi, Rahayu Kartika. (2013) "Pengaruh Manajemen Laba Sebelum Initial Public Offerings Terhadap Kinerja Keuangan Serta Dampaknya Terhadap Return Saham Pada Perusahaan Di Bursa Efek Indonesia”. Tesis. Program Pascasarjana. Universitas Diponegoro

Feliana, Yie Ke. (2007) "Pengaruh Struktur Kepemilikan Perusahaan dan Transaksi dengan Pihak-Pihak yang Memiliki Hubungan Istimewa Terhadap Daya Informasi Akuntansi”. Simposium Nasional Akuntansi X, Makasar.

Forum for Corporate Governance in Indonesia, Seri Tata Kelola Perusahaan (Corporate Governance) Jilid II; Peranan Dewan Komisaris dan Komite Audit dalam Pelaksanaan Corporate Governance.

Gagola, Antonius S.C. (2011) "Analisis Faktor Risiko Yang Mempengaruhi Kecenderungan Kecurangan Pelaporankeuangan Perusahaan Publik Di Indonesia". Tesis Tidak Dipublikasikan, Program Studi Magister Akuntansi program Pasca sarjana, Universitas Diponegoro 
Ghozali, Imam. (2011) Aplikasi Analisis Multivariate dengan Program SPSS. Badan penerbit Universitas Diponegoro, Semarang

Gunarsih, T dan Hartadi, B. (2002) "Pengaruh Pengunguman Pengangkatan Komisaris Independen Terhadap Return Saham di Bursa Efek Jakarta." Junal Riset Akuntansi, Manajemen dan Ekonomi, 2 (2), 104-120.

Halim, J., C. Meiden, and R.L. Tobing. (2005) "PengaruhManajemen Laba pada Tingkat Pengungkapan Laporan Keuangan pada Perusahaan Manufaktur yang Termasuk dalam Indeks LQ-45". SNA VIII. Solo, 117-135

Guna, I. W dan A. Herawaty. (2010) "Pengaruh Mekanisme Good Corporate Governance, Independensi Auditor, Kualitas Audit dan faktor lainnya terhadap Manajemen Laba”. Jurnal Bisnis dan Akuntansi 12 (1), 53-68.

Herman, Ridha Yani., dan Shiddiq NH., (2013) "Manajemen Laba Melalui Transaksi Pihak Istimewa di Sekitar Penawaran Saham Perdana". Diponegoro Journal of Accounting, 2 (3), 1-8.

Ikatan Akuntan Indonesia. (2015) Standar Akuntansi Keuangan. Cetakan pertama: Nopember 2014. Penerbit IAI: Jakarta

Jian Ming. (2003) "Earnings Mangement and Tunneling Through Related Party Transaction: Evidence from Chinese Corporate Groups". A Thesis of Hong Kong University. Diakses: http://search.proquest.com

Krishnan, J. and Ye, Z. (2005) "Why some companies seek shareholder ratification on auditor selection. Accounting Horizons. 19(4), 237-255

Kurniawati, Ema dan Surya Raharja. (2012) "Analisis Faktor-Faktor Yang Mempengaruhi Financial Statement Fraud Dalam Perspektif Fraud Triangle". Universitas Diponegoro. Diakses : 〈http://eprints.undip.ac.id>

Kusumawardhani, Indra. (2012) "Pengaruh Corporate Gorvenance, Struktur Kepemilikan, dan Ukuran Perusahaan Terhadap Manajemen Laba”. Jurnal Akuntansi dan Sistem Informasi Teknologi. 9 (1), 41-61

Lister, L.M. (2007) “A Practical Approach to Fraud Risk": Internal Auditors.

Lou, Y.I. and Ming-Long Wang. (2009) "Fraud Risk Factor Of The Fraud Triangle Assessing The Likelihood Of Fraudulent Financial Reporting". Journal of Business \& Economics Research, 7 (2), 61-78

Manurung, D.T.H. and N. Hadian. (2013) "Detection Fraud of Financial Statement with Fraud Triangle". Proceedings of 23rd International Business Research Conference. Marriott Hotel: Melbourne, Australia.

Mulford, C. dan Eugene Comiskey. (2010) "The Financial Numbers Game Detecting Creative Accounting Theory". New York: John Wiley and Sons, Inc.

Myers, J. N., L. A. Myers, and T. C. Omer. (2003) "Exploring the term of the auditorclient relationship and the quality of earnings: A case for mandatory auditor rotation?". The Accounting Review 78 (3), 779-800.

Nguyen, Khanh. (2008) "Financial Statement Fraud: Motives, Methodes, Cases and Detection.” Florida. Diakses : http://www.bookpump.com

Norbarani, Listiana. (2012) Pendeteksian Kecurangan Laporan Keuangan Dengan Analisis Fraud Triangle Yang Diadopsi Dalam Sas No.99. Diakses: <http://eprints.undip.ac.id/35524/1/Skripsi_32.pdf>

Noviana, S. R. dan Yuyetta, E. N. A., Analisis Faktor - Faktor Yang Mempengaruhi Praktik Perataan Laba Studi Empiris Perusahaan Manufaktur Yang 
Terdaftar Di BEI Periode 2006-2010, Skripsi, Universitas Diponegoro, Semarang. Diakses : <http://eprints.undip.ac.id>

Nugroho Sigit A dan Binekasri Romys, VivaNews 30 Desember 2014. Diakses: http://bisnis.news.viva.co.id/news/read/573320-ojk-denda-777-emiten-nakal-selama2014.

Prastowo, Dwi D., (2011) Analisis Laporan Keuangan, Konsep dan Aplikasi. Edisi Ketiga, Penerbit UPP STIM YKPN, Jakarta.

Priantara, Diaz, (2013) Fraud Auditing \& Investigation, Penerbit Witra Wacana Media, Jakarta

Utami, Rini Budi dan Rahmawati. (2008) "Pengaruh Komposisi Dewan Komisaris Dan Keberadaan Komite Audit Terhadap Aktivita Manajemen Laba Pada Perusahaan Manufaktur Yang Terdaftar Di Bursa Efek Jakarta". Seminar Ketahanan Ekonomi Nasional. UPN Yogyakarta.

Restuningdiah, Nurika. (2011) "Komisaris Independen, Komite Audit, Internal Audit dan Risk Management Committee terhadap Manajemen Laba". Jurnal Keuangan dan Perbankan, 5 (3), 351-362.

Rusli, Iskandar. (2009) "Pengaruh Aset dan Manajemen Inventory terhadap Manajemen Laba". Jurnal Ilmu Administrasi dan Organisasi, Sept-Des 2009, Volume 16, Nomor 3 hlm.160-169 ISSN 0854-3844.

Santoso, Yosika Tri. (2009) Analisis Pengaruh NPM, ROA, Company Size, Financial Leverage dan DER Terhadap Praktek Perataan Laba Pada Perusahaan Property dan Real Estate yang Terdaftar di Bursa Efek Indonesia. Fakultas Ekonomi Universitas Gunadarma. Diakses: http://repository.gunadarma.ac.id

Shu, S. Z. (2000) "Auditor resignations: clientele effects and legal liability". Journal of Accounting and Economics. 29(2), 173 - 205

Skousen, C.J., K.R. Smith dan C.J. Wright. (2009) "Detecting and Predicting Financial Statement Fraud : The Effectiveness of The Fraud Triangle and SAS no. 99", Journal of Corporate Governance and Firm Performances, 13, 53-81 Suyanto

Sorenson, J. E., H. D. Grove, and F. H. Selto, (1983) "Detecting Management Fraud: An Empirical Approach". Symposium on Auditing Research, 5, 73-116.

Sukirman dan M.P. Sari. (2013) "Model Deteksi Kecurangan Berbasis Fraud Triangle (Studi Kasus Pada Perusahaan Publik Di Indonesia)". Jurnal Akuntansi dan Auditing, 9 (2), 199-225.

Summers, S., \& Sweeney, J. (1998) "Fraudulent misstated financial statements and insider trading: An empirical analysis". The Accounting Review, 73(January), 131-146.

Ujiyantho, Arief dan Bambang Agus Pramuka. (2007) "Mekanisme Corporate Governance, Manajemen Laba Dan Kinerja Keuangan (Studi Pada Perusahaan Go Publik Sektor Manufaktur)", Jurnal dan Prosiding SNA - Simposium Nasional Akuntansi, volume 10.

www.idx.co.id

www.portalstatistik.com

www.sahamok.com

www.spssindonesia.com

Young, B. (2005) "Related-Party Transactions: Why They Matter and What Is Disclosed". The Corporate Governance Advisor, Vol. 13 (4), 1-7. 